\title{
Penyelenggaraan Praktikum Pola Blok 1 X 10 dan 10 X 1 sebagai Acuan Kebijakan Praktikum Laboratorium IPA
}

\author{
S. Suhirman \\ Program Studi Tadris IPA Biologi FTK UIN Mataram, Jln. Gajah Mada 100 Jempong Baru Mataram \\ 83116, Indonesia \\ *Corresponding Author e-mail: suhirman@uinmataram.ac.id
}

Received: June 2020; Revised: June 2020; Published: July 2020

\begin{abstract}
Abstrak
Salah satu rekomendasi asesor pada visitasi BAN PT dalam rangka Akreditasi Jurusan Tadris IPA Biologi, Fakultas Tarbiyah dan Keguruan UIN Mataram adalah praktikum Laboratorium IPA dilakukan dengan pola 10x1, sementara penyelenggaraan praktikum yang umum dilaksanakan adalah pola blok 1x10. Tujuan penelitian eksperimental ini adalah menguji efektivitas penyelenggaraan praktikum pola blok 1×10 dan 10x1 sebagai acuan kebijakan praktikum Laboratorium IPA. Efektivitas dilihat dari tiga komponen, yaitu: nilai tes praktikum, nilai laporan praktikum, dan preferensi praktikan dan co-asisten terhadap salah satu pola praktikum. Penelitian dilakukan pada mahasiswa Jurusan S1 PGMI Semester II, Jurusan Tadris IPA Biologi Semester IV, dan Co-Asisten. Rancangan penelitian adalah quasi eksperimental dengan tipe Pre-test-postest Non-Equivalen pada sampel yang diambil secara cluster random sampling. Data dikumpulkan dengan teknik tes, angket, dan wawancara untuk kemudian dianalisis dengan statistik inferensial pada taraf signifikansi 0,05. Hasil penelitian menunjukkan, bahwa nilai tes dan nilai laporan praktikum mahasiswa yang mengikuti praktikum pola blok $10 \times 1$ lebih tinggi dibanding $1 \times 10$, tetapi tidak berbeda secara signifikan. Berdasarkan analisis diperoleh $96 \%$ mahasiswa lebih menyukai pola praktikum $10 \times 1$. Dengan demikian, ditinjau dari hasil, salah satu pola praktikum tidak ada yang lebih efektif dibanding yang lain.
\end{abstract}

Kata Kunci: Efektivitas, praktikum, pola blok 1 x 10, pola $10 \times 1$, preferensi

\section{Organizing Practicum of 1 X 10 and 10 X 1 Block Patterns as a Reference for Science Laboratory Practicum Policy}

\begin{abstract}
One of the recommendations from BAN PT assessors during the visitation in the Accreditation of Department of Natural Sciences, Faculty of Education and Teacher Training is that practicum at Natural Science Laboratory should be administered in a $10 x 1$ block pattern, while the general administration of practicum pattern is a $1 \times 10$ block pattern. This experiment aimed at investigating the effectiveness of the administration of the $1 \times 10$ and 10x1 block practicum patterns. The effectiveness was sought out by assessing three components, namely: practicum test scores, practicum report scores and the preferences of practicants and co-assistants to one of the practicum patterns. The participants of this study were the second year undergraduate students of elemetary Education Department and the fourh year undergraduate students of Natural Science Education Department, and cosssistants. This study was of quasi-experiment using Non-Equivalent Pre-test-postest design and the sample was taken using cluster random sampling technique. The data were collected through test, questionnaire, and interview and then they were analyzed using inferential statistics at the 0.05. significance level. The findings showed that the test and practicum report scores of the students who joined the $10 \times 1$ block practicum pattern were higher than those who joined $1 \times 10$ block practicum pattern, yet they did not differ significantly. Based on the analysis, $96 \%$ of the students obviously preferred the $10 \times 1$ block practicum pattern. Thus, based on the results, no one practicum pattern was more effective than the other.
\end{abstract}

Keywords: Effectiveness, practicum, $1 \times 10$ block pattern, $10 \times 1$ block pattern, preference

How to Cite: Suhirman, S. (2020). Penyelenggaraan Praktikum Pola Blok 1 X 10 dan 10 X 1 sebagai Acuan Kebijakan Praktikum Laboratorium IPA. Jurnal Penelitian dan Pengkajian Ilmu Pendidikan: eSaintika, 4(2), 211-222. doi:https://doi.org/10.36312/e-saintika.v4i2.251 


\section{PENDAHULUAN}

Ilmu Pengetahuan Alam (IPA) memiliki peran yang sangat penting untuk membentuk pengembangan dan kesadaran seseorang (Rochmawati, Wiyanto, \& Ridlo, 2019). IPA merupakan kumpulan pengetahuan yang disusun secara sistematis, dirumuskan dan diperoleh dengan menggunakan metode ilmiah (Istiana, Sarwi, \& Masturi, 2016). Salah satu kegiatan yang menerapkan metode ilmiah dalam pembelajaran IPA biologi adalah kegiatan praktikum (Siburian, Sinambela, \& Septie, 2014). Pembelajaran IPA menjadi lebih bermakna manakala dilakukan melalui pengamatan, bereksperimen, mencoba, atau memproduksi produk untuk memberikan pengalaman belajar (Trnova \& Trna, 2015). Para ilmuwan IPA dalam mempelajari gejala alam menggunakan proses dan sikap ilmiah. Proses ilmiah melalui pengamatan, eksperimen, dan analisis yang bersifat rasional dan sikap ilmiah seperti objektif dan jujur dalam mengumpulkan data (Vyjantimala, Lum, Mui, \& Hong, 2002). Dengan menggunakan proses dan sikap ilmiah, para saintis memperoleh penemuanpenemuan atau produk dan pengetahuan. IPA sebagai pengetahaun mencakup keterampilan, keingintahuan, keteguhan hati, dan keterampilan dalam hal melakukan penyelidikan ilmiah (Ali, 2018; Abruscato, 2014; Sudarisman, 2015; Ruse, 2012). IPA sebagai produk mencakup fakta, konsep, prinsip, hukum-hukum, dan teori IPA (Carin, 1999; Susanti, Rusilxowati, \& Susanto, 2015).

Hakikatnya IPA terdiri atas tiga komponen, yaitu sikap ilmiah, proses ilmiah, dan produk ilmiah. Hal ini berarti bahwa IPA tidak hanya terdiri atas kumpulan pengetahuan atau berbagai macam fakta yang dihafal, IPA juga merupakan kegiatan atau proses aktif menggunakan pikiran dalam mempelajari gejala-gejala alam yang belum dapat direnungkan. IPA menggunakan apa yang telah diketahui sebagai batu loncatan untuk memahami apa yang belum diketahui. Suatu masalah IPA yang telah dirumuskan dan kemudian berhasil dipecahkan akan memungkinkan IPA untuk berkembang secara dinamis. Akibatnya kumpulan pengetahuan sebagai produk juga bertambah. Salah satu cara yang dilakukan untuk mempelajari gejala alam melalui kegiatan praktikum. Kemampuan untuk melakukan kegiatan laboratorium merupakan elemen penting dalam pembelajaran sains (Hodson, 1996). Shulman \& Tamir (1973) dalam Trumper (2002) menyatakan bahwa pengalaman laboratorium adalah inti (core) dari proses pembelajaran sains. Pembelajaran sains yang dimaksudkan seperti mengamati dan memahami fenomena alam (Mao \& Chang, 1998). Pembelajaran sains menggunakan metode berbasis laboratorium relevan untuk mengembangkan keterampilan ilmiah, meningkatkan pemahaman konsep dan mengembangkan keterampilan berpikir kreatif, termasuk juga untuk menumbuhkan sikap ilmiah sebagai bekal untuk masa depan seseorang (McDermott, 1990).

Laboratorium merupakan tempat dilakukannya percobaan dan penelitian (Marcella, Susanti, \& Dani, 2018). Laboratorium dilengkapi sejumlah peralatan yang dapat digunakan siswa untuk melakukan eksperimen atau percobaan dalam sains, melakukan pengujian dan analisis, melangsungkan penelitian ilmiah, ataupun paraktek pembelajaran dalam sains. Sains di laboratorium dimaksudkan untuk memberikan pengalaman memanipulasi berbagai peralatan dan bahan laboratorium dan juga membantu siswa untuk pengembangan pemahaman konseptual (Trumper, 2002). Secara teoritis keberadaan laboratorium diharapkan mampu menunjang kegiatan-kegiatan yang berpusat pada pengembangan keterampilan tertentu, antara lain keterampilan proses, keterampilan motorik dan pembentukan sikap ilmiah, khususnya pengembangan minat untuk melakukan penyelidikan, penelitian dan minat mempelajari alam secara lebih mendalam (Hudha, 2011). 
Sarana dan prasarana laboratorium yang baik diperlukan untuk menunjang kegiatan praktikum agar kegiatan praktikum dapat berjalan dengan lancar (Siburian et al., 2014). Sains di laboratorium dimaksudkan untuk memberikan pengalaman memanipulasi berbagai peralatan dan bahan laboratorium dan juga membantu siswa untuk pengembangan pemahaman konseptual (Trumper, 2002). Tujuan pembelajaran berbasis laboratorium adalah melakukan kegiatan mengamati fenomena alam, mengembangkan pemahaman tentang peristiwa yang diamati dan menghubungkan pengetahuan ilmiah dengan keterampilan berpikir kritis dan juga untuk membuat siswa/mahasiswa merasa bahagia dan bersemangat dalam belajar (Nugent, Kunz, Levy, Harwood, \& Carlson, 2008).

Pembelajaran sains menggunakan metode berbasis laboratorium relevan untuk mengembangkan keterampilan ilmiah, meningkatkan pemahaman konsep dan mengembangkan keterampilan berpikir kreatif, termasuk juga untuk menumbuhkan sikap ilmiah sebagai bekal untuk masa depan guru (McDermott, 1990). Sementara itu, tujuan pembelajaran sains berbasis laboratorium adalah untuk melakukan kegiatan mengamati fenomena alam, mengembangkan pemahaman tentang peristiwa yang diamati dan menghubungkan pengetahuan ilmiah dengan keterampilan berpikir kritis dan juga untuk membuat siswa/mahasiswa merasa bahagia dan bersemangat dalam belajar (Nugent, Kunz, Levy, Harwood, \& Carlson, 2008).

Kegiatan praktikum di jurusan Tadris IPA Biologi, Fakultas Tarbiyah dan Keguruan UIN Mataram merupakan bagian integral dari kurikulum inti yang pelaksanaannya dilakukan di Laboratorium IPA Biologi. Selama beroperasinya jurusan Tadris IPA Biologi Fakultas Tarbiyah dan Keguruan UIN Mataram, penyelenggaraan kegiatan praktikum dilakukan dengan pola blok 1 x 10. Makna pola blok 1 × 10 adalah setiap mata kuliah memiliki sejumlah mata acara yang harus dipraktikumkan, setiap mata acara memerlukan waktu 1 hingga 2 jam. Penyelenggaraan praktikum pola blok 1 x 10 adalah semua mata acara praktikum dalam satu mata kuliah dilaksanakan dalam satu waktu, biasanya dalam satu hari. Pola ini memiliki kelebihan dan kekurangan, di antara kelebihannya adalah praktikum bisa selesai dengan cepat. Sedangkan kekurangan pola 1 × 10 adalah mahasiswa dipaksa untuk menyelesaikan semua mata acara dengan mengabaikan kemampuannya dalam menyerap sekian banyak informasi dan tidak mengedepankan keterampilan mahasiswa dalam menggunakan alat dan bahan. Salah satu pola penyelenggaraan praktikum yang lain adalah pola $10 \times 1$. Pola $10 \times 1$ maksudnya, bahwa setiap 1 mata acara praktikum dilaksanakan dalam 1 waktu atau dalam 1 minggu, sehingga misalnya satu mata kuliah memiliki maksimum 10 mata acara praktikum, berarti dapat dilaksanakan dalam waktu 10 minggu.

Pada saat visitasi BAN PT dalam rangka akreditasi Jurusan Tadris IPA Biologi, Fakultas Tarbiyah dan Keguruan UIN Mataram, salah satu rekomendasi yang diberikan oleh asesor adalah berkaitan dengan penyelenggaran praktikum. Asesor memberikan rekomendasi penyelenggaraan praktikum dilakukan dengan pola $10 \times 1$ agar penyelenggaraan praktikum memberikan kesempatan kepada mahasiswa untuk memantapkan keterampilan dan memberikan waktu yang lebih banyak untuk mendiskusikan hasil-hasil percobaan maupun pengamatan selama praktikum.

Sebagai pola baru yang ditawarkan adalah pola penyelenggaraan $10 \times 1$ yang belum diketahui kelebihan dan kekurangannya di lapangan. Di satu sisi pola blok $1 \mathrm{x}$ 10 juga belum diketahui apakah tidak lebih baik dibanding pola $10 \times 1$. Melalui penelitian eksperimental ini diharapkan dapat menemukan satu formulasi yang tepat 
mengenai penyelenggaraan praktikum pada laboratorium IPA UIN Mataram dan dijadikan salah satu acuan kebijkan UIN Mataram dalam penyelenggaran praktikum.

Rumusan masalah penelitian ini adalah bagaimana efektivitas penyelenggaraan praktikum pola blok $1 \times 10$ dan $10 \times 1$ sebagai acuan kebijakan praktikum jurusan Tadris IPA Biologi pada laboratorium IPA UIN Mataram. Rumusan masalah umum tersebut dapat dirinci secara operasional yang lebih khusus, sebagai berikut: (1) bagaimana nilai tes praktikum mahasiswa yang mengikuti praktikum pola blok $1 \mathrm{x}$ 10 dengan pola $10 \times 1$, (2) bagaimana nilai laporan praktikum mahasiswa yang mengikuti praktikum pola blok $1 \times 10$ dengan pola $10 \times 1$, (3) bagaimana preferensi kesukaan praktikan dan co-asisten terhadap praktikum pola blok $1 \times 10$ dengan pola $10 \times 1$, dan (4) bagaimana kelebihan dan kekurangan penyelenggaraan praktikum pola blok $1 \times 10$ dengan pola $10 \times 1$.

Kebaruan dalam penelitian ini adalah menemukan satu formulasi yang tepat dan efektif mengenai penyelenggaraan praktikum pada laboratorium IPA FTK UIN Mataram yang selanjutnya dijadikan sebagai salah satu acuan kebijkan UIN Mataram dalam penyelenggaran praktikum yang dilaksanakan di Laboratorium Terpadu IPA.

\section{METODE}

Strategi penelitian ini merupakan penelitian eksperimen. Dikatakan penelitian eksperimen karena memberikan perlakuan pada sampel dan membandingkan efek perlakuan dengan kelompok lain yang diberi perlakuan yang berbeda. Dalam penelitian ini, satu kelompok (kelas) mahasiswa diberikan perlakuan praktikum dengan pola blok $1 \times 10$ dan kelompok lain sebagai pembanding diberikan perlakuan praktikum dengan pola $10 \times 1$. Efek yang ditimbulkan akibat perlakuan tersebut adalah efektivitas penyelenggaraan praktikum.

Jenis dan sumber data penelitian adalah mahasiswa Jurusan S1 PGMI Semester II, Jurusan Tadris IPA Biologi semester IV, Fakultas Tarbiyah dan Keguruan UIN Mataram yang berjumlah 7 kelas dan co-asisten praktikum. Populasi dikelompokkan lagi ke dalam tiga sub populasi, yaitu: mahasiswa jurusan S1 PGMI semester II sebagai sub-populasi 1 yang berjumlah 3 kelas, mahasiswa jurusan Tadris IPA Biologi semester IV sebagai sub-populasi 2 yang berjumlah 4 kelas, dan co-asisten sebagai sub-populasi 3. Untuk tujuan membandingkan nilai tes dan nilai laporan mahasiswa, sampel diambil dari populasi 1. Sampel diambil 2 kelas dengan teknik Cluster Random Sampling, karena anggota populasi berada pada kelompok atau kelas-kelas (Tuckman, 1978). Satu kelas sampel diberikan perlakuan praktikum dengan pola blok 1 x 10 dan satu kelas yang lainya diberikan perlakuan praktikum dengan pola $10 \times 1$, sedangkan untuk menentukan preferensi (tingkat kesukaan) mahasiswa terhadap salah satu pola praktikum dan untuk mendeskripsikan kelebihan dan kekurangan masing-masing pola praktikum, sampel ditarik dari populasi 2 dan 3. Dijadikannya mahasiswa jurusan Tadris IPA Biologi semester IV yang mengikuti bersama-bersama dua pola praktikum yang dicobakan. Jenjang semester dalam populasi penelitian ini diasumsikan tidak memberikan efek yang berarti terhadap variabel bebas, sehingga dapat diabaikan, dan pengambilan sampel tidak dilakukan secara stratified random sampling.

Desain penelitian yang digunakan adalah desain eksperimental semu dengan tipe pre-test-postest non-equivalen (Tuckman, 1978).

$$
\begin{aligned}
& 0_{1} \mathrm{X}_{1} 0_{2} \\
& 0_{3} \mathrm{X}_{2} 0_{4}
\end{aligned}
$$


Keterangan:

$\mathrm{X}_{1}=$ Kelas yang diberi perlakuan praktikum pola blok $1 \times 10$

$\mathrm{X}_{2} \quad=$ Kelas yang diberi perlakuan praktikum pola $10 \times 1$

$0_{1} \& 0_{3} \quad=$ kondisi awal

$02 \& 0_{4} \quad=$ kondisi akhir setelah perlakuan

Teknik pengumpulan data dilakukan dengan teknik tes, angket, checklist, dan wawancara. Penggunaan tes dengan memberikan perangkat soal kepada mahasiswa setelah selesai rangkaian kegiatan praktikum mata kuliah selesai. Metode tes digunakan untuk mengumpulkan data tentang nilai praktikum mahasiswa yang mengikuti praktikum pola blok $1 \times 10$ dengan pola $10 \times 1$. Tes diberikan sebelum dan sesudah penyelenggaraan praktikum. Angket merupakan metode yang digunakan oleh peneliti dalam menjaring data tentang: (1) preferensi praktikan dan co-asisten terhadap dua pola praktikum yang berbeda, (2) kelebihan dan kekurangan penyelenggaraan praktikum pola blok $10 \times 1$ dan pola $1 \times 10$. Metode checklist merupakan metode tabulasi untuk mendapatkan data tentang: (1) kualitas laporan praktikum mahasiswa dan (2) skor tingkat kemudahan penyiapan jadwal dan alat dan bahan praktikum. Wawancara merupakan metode tanya jawab dengan responden. Metode wawancara digunakan untuk mendapatkan data tentang kelebihan dan kekurangan praktikum pola blok $1 \times 10$ dan pola $10 \times 1$. Wawancaran yang dilakukan bersifat tertutup dan terbuka. Teknik analisis data dalam penelitian ini menggunakan teknik statistik inferensial. Statistik inferensial yaitu menganalisis sebagian data untuk kemudian sampai pada peramalan atau penarikan kesimpulan mengenai seluruh data induknya atau populasi. Analisis data menggunakan; Statistik-t, statistik deskritptif, dan analisis deskriptif kualitatif.

Uji-t digunakan untuk mengetahui perbedaan yang signifikan: (1) data nilai praktikum mahasiswa dan (2) nilai laporan praktikum mahasiswa yang mengikuti praktikum pola blok $1 \times 10$ dan pola $10 \times 1$. Semua analisis data secara statistik dalam penelitian ini dilakukan dengan menggunakan program SPSS Versi 10.2 pada Windows XP. Penarikan simpulan pada setiap unit analisis dilakukan pada taraf nyata (a) 0.05. Efektivitas suatu pola praktikum akan diindikasikan melalui parameter-parameter statistik yang berupa: (1) nilai tes praktikum yang tinggi; (2) nilai laporan praktikum mahasiswa yang tinggi; dan (3) preferensi kesukaan praktikan dan co-asisten terhadap salah satu pola praktikum.

\section{HASIL DAN PEMBAHASAN}

Uji homogenitas dilakukan untuk mengetahui apakah dua sampel penelitian memiliki varians yang sama atau memiliki kemampuan kognitif awal yang sama. Dua sampel tersebut yaitu mahasiswa jurusan S1 PGMI Semester II Kelas A yang berjumlah 34 orang sebagai kelas perlakuan pola $10 \times 1$, dan mahasiswa kelas B yang berjumlah 32 orang sebagai kelas perlakuan pola blok $1 \times 10$. Hasil uji homogenitas kemampuan awal mahasiswa disajikan pada Tabel 1.

Tabel 1. Hasil uji homogenitas kemampuan awal mahasiswa

\begin{tabular}{lccc}
\hline Levene Statistic & df1 & df2 & Sig. \\
\hline 0,302 & 2 & 89 & 0,740
\end{tabular}

Hasil pada Tabel 1 tampak bahwa nilai probabilitas yang didapat adalah 0,74 lebih besar dari signifikansi yang diajukan yaitu 0.05. Ini berarti bahwa H0 yang 
menyatakan bahwa varians kedua sampel sama, diterima. Dengan demikian, kemampuan kognitif awal antara kelas IIA dengan IIB adalah homogen.

Setiap kelas sampel diberi perlakuan praktikum mata kuliah IPA1 dengan jumlah mata acara 9. Kelas IIA dilakukan praktikum $10 \times 1$ atau setiap minggu dilakukan kegiatan praktikum dengan mata acara yang berbeda, sehingga kegiatan praktikum berlangsung selama 9 minggu. Kelas IIB dilakukan praktikum dengan pola Blok 1 x 10 atau praktikum dilakukan sekaligus dalam satu minggu. Setelah selesai seluruh rangkaian kegiatan praktikum, kemudian setiap kelas diberikan tes akhir. Pemberian tes akhir dilakukan untuk mengukur kemampuan mahasiswa menguasai materi praktikum, baik hasil maupun proses. Data hasil tes akhir mahasiswa dapat dilihat pada Tabel 2.

Tabel 2. Perbandingan nilai tes akhir mahasiswa setelah praktikum

\begin{tabular}{lcc}
\hline Parameter & Kelas IIA $(10 \times 1)$ & Kelas IIB $(1 \times 10)$ \\
\hline Jumlah mahasiswa & 34 & 32 \\
Nilai tertinggi & 80 & 85 \\
Nilai terendah & 50 & 50 \\
Rata-rata & 63.90 & 66.64 \\
Simpangan baku & 8.73 & 8.81 \\
\hline
\end{tabular}

Berdasarkan Tabel di atas, tampak bahwa setelah dilakukan kegiatan praktikum dengan pola yang berbeda menyebabkan perbedaan nilai tes yang diperoleh mahasiswa. Rata-rata nilai mahasiswa kelas IIB lebih tinggi dibanding nilai rata-rata kelas IIA. Untuk menentukan apakah nilai rata-rata kedua kelas tersebut berbeda secara signifikan (nyata) atau tidak, dilakukan uji statistik dengan statistik-t pada taraf nyata 5\%. Hasil analisis menunjukkan, bahwa nilai signifikansi perhitungan $=0.270$, lebih besar dari nilai signifikansi yang diajukan, yaitu 0.05 . Hal ini berarti bahwa H0 diterima, dengan demikian, tidak terdapat perbedaan yang signifikan nilai tes mahasiswa yang mengikuti praktikum dengan pola blok $1 \times 10$ dengan pola $10 \times 1$.

Di samping mengadakan tes, setelah selesai seluruh rangkaian kegiatan praktikum juga mahasiswa diharuskan untuk membuat laporan akhir praktikum untuk semua mata acara yang dipraktikumkan. Nilai laporan ini merupakan salah satu bagian dari penilaian praktikum, di samping nilai tes dan aktivitas yang lain. Data nilai laporan praktikum mahasiswa dapat dilihat pada tabel 3 di bawah ini.

Tabel 3. Perbandingan nilai laporan praktikum mahasiswa setelah dilakukan praktikum

\begin{tabular}{lcc}
\hline Parameter & Kelas IIA $(10 \times 1)$ & Kelas IIB $(1 \times 10)$ \\
\hline Jumlah mahasiswa & 34 & 32 \\
Nilai tertinggi & 90.67 & 85.67 \\
Nilai terendah & 60 & 33.33 \\
Rata-rata & 77.14 & 73.2 \\
Simpangan baku & 6.87 & 10.36 \\
\hline
\end{tabular}

Tabel 3 menunjukkan bahwa setelah dilakukan kegiatan praktikum dengan pola yang berbeda, nilai laporan praktikum yang diperoleh mahasiswa berbeda pula. Ratarata nilai mahasiswa kelas IIA lebih tinggi dibanding nilai rata-rata kelas IIB. Untuk menentukan apakah nilai rata-rata kedua kelas tersebut berbeda secara signifikan, dilakukan uji statistik dengan statistik-t pada taraf nyata 5\%. Hasil analisis menunjukkan, bahwa nilai signifikansi perhitungan $=0.071$, lebih besar dari nilai 
signifikansi yang diajukan, yaitu 0.05. Hal ini berarti bahwa H0 diterima, dengan demikian, tidak terdapat perbedaan yang signifikan nilai laporan praktikum mahasiswa yang mengikuti praktikum pola blok $1 \times 10$ dengan pola $10 \times 1$.

Data mengenai kesukaan mahasiswa dan co-asisten terhadap salah salah satu pola praktikum yang diselenggarakan, dikumpulkan dengan menggunakan angket preferensi. Angket diberikan secara random pada mahasiswa jurusan Tadris IPA Biologi semester IV. Subjek tersebut telah mengalami proses pelaksanaan praktikum sekaligus dengan dua pola yang diujikan dalam penelitian ini pada mata kuliah yang berbeda. Sebagai contoh, mata kuliah Taksonomi Tumbuhan Rendah dilakukan dengan pola $10 \times 1$ dan mata kuliah Morfologi Tumbuhan dilakukan dengan pola blok $1 \times 10$.

Hasil analisis data angket yang dihimpun dari 25 orang sampel mahasiswa jurusan Tadris IPA Biologi semester IV dan 10 orang co-asisten, diperoleh gambaran bahwa 33 orang (96\%) mahasiswa dan co-asisten menyatakan lebih menyukai pola praktikum $10 \times 1$ atau praktikum yang dilaksanakan setiap minggu. Dua orang mahasiswa dan co-asisten (6\%) menyukai praktikum dengan pola $1 \times 10$. Dengan demikian, dapat dikatakan bahwa pola praktikum $10 \times 1$ lebih disukai mahasiswa dibanding pola $1 \times 10$. Gambaran deskriptif mengenai perbandingan prefereensi mahasiswa dapat dilihat pada Gambar 1 berikut.

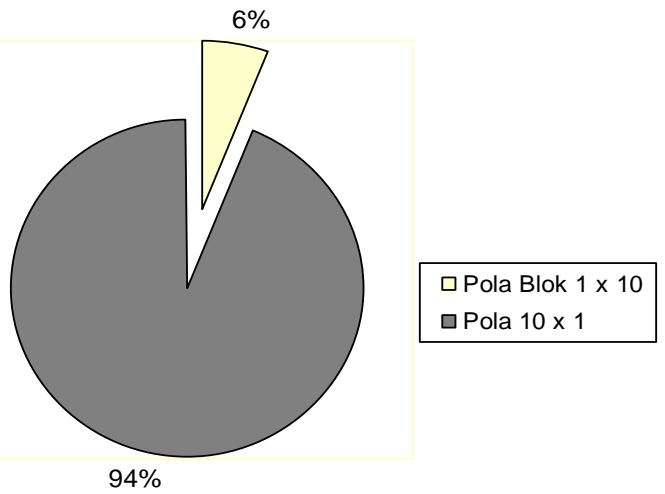

Gambar 1. Rasio mahasiswa dan co-asisten yang memilih dua jenis pola praktikum yang diberlakukan

Setiap jenis pola praktikum yang diterapkan pada penyelenggaraan praktikum pada laboratorium memiliki kelebihan dan kekurangan masing-masing. Penelitian ini berhasil menghimpun data tentang kelebihan dan kekurangan masing-masing kedua pola penyelenggaraan praktikum yang dicobakan pada laboratorium IPA Fakultas Tarbiyah dan Keguruan UIN Mataram. Data tersebut diperoleh dengan melakukan wawancara terbuka terhadap responden mahasiswa praktikan dan co-asisten pendamping praktikum. Data mengenai kelebihan dan kekurangan masing-masing pola praktikum seperti yang terlihat pada Tabel 4 berikut.

Tabel 4. Kelebihan dan kekurangan penyelenggaraan praktikum

\begin{tabular}{rll}
\hline Aspek & \multicolumn{1}{c}{ Pola Blok $1 \times 10$} & \multicolumn{1}{c}{ Pola $10 \times 1$} \\
\hline Kelebihan & - Praktikum tidak & - Praktikan bisa lebih \\
& membutuhkan banyak waktu & memahami materi \\
& - Praktikum lebih mudah & paraktikum karena tersedia \\
& diorganisir. & waktu yang cukup untuk \\
& - Dapat melakukan semua acara & menelaah dan mencari kajian- \\
& secara beruntun sehingga & kajian tambahan. \\
\hline
\end{tabular}




\begin{tabular}{cll}
\hline Aspek & \multicolumn{1}{c}{ Pola Blok $1 \times 10$} & \multicolumn{1}{c}{ Pola $10 \times 1$} \\
\hline & pemahaman menjadi & - Praktikan bisa terfokus \\
sinambung. & dengan satu materi \\
& praktikum \\
& & - Tersedia waktu untuk \\
& mendiskusikan permasalahan \\
& yang ditemukan pada waktu \\
& praktikum dan menyusun \\
Kekurangan & - Ada tujuan acara praktikum & - Praktikan terkadang merasa \\
& yang tidak tercapai & bosan karena setiap waktu \\
- Memerlukan persiapan alat & luang digunakan untuk \\
dan bahan secara ketat. & praktikum. \\
- Waktu penyelesaian laporan & - Co-assisten yang \\
praktikum sangat singkat. & membimbing praktikum juga \\
& tidak tersedia banyak waktu \\
& karena mereka juga kuliah \\
\hline
\end{tabular}

Pelaksanaan kegiatan praktikum memiliki peranan yang sangat penting untuk mendukung kualitas hasil dan proses pembelajaran. Kegiatan praktikum juga sangat efektif untuk meningkatkan keahlian mahasiswa dalam menggunakan maupun memanfaatkan alat dan bahan laboratorium. Kegiatan praktikum dapat mengembangkan rasa ingin tahu mahasiswa, menumbuhkan keaktifan, sikap kerjasama, ketelitian, toleran, serta menumbuhkan kejujuran ilmiah.

Praktikum merupakan salah satu bentuk kegiatan ilmiah dalam IPA. Istilah praktikum dalam pendidikan IPA merujuk pada aktivitas-aktivitas laboratorium dan non-laboratorium (lapangan) untuk membuktikan kebenaran atau ketidakbenaran fakta, konsep, prinsip, dan teori yang diungkap di dalam perkuliahan. Praktikum tidak hanya semata-mata membuktikan, tetapi juga merupakan kegiatan dalam rangka membangun (mengkonstruksi) pengetahuan melalui interaksi dengan objek (alam), sebagaimana saintis bekerja dalam menemukan ilmu pengetahuan. Menurut Carin (1999) IPA dikembangkan sesuai dengan hakikat pembelajarannya yaitu ke arah pengembangan scientific processes, scientific products, scientific attitudes. Laboratorium merupakan tempat dilakukannya percobaan dan penelitian (Marcella, Susanti, \& Dani, 2018).

Praktikum sebagai manifestasi kegiatan mempelajari objek alam untuk mengkonstruksi pengetahuan merupakan bagian yang terintegrasi dalam suatu bidang ilmu. Dalam melakukan penyelidikan mahasiswa secara aktif mengamati, merumuskan masalah, mengajukan atau merumuskan hipotesis, mengumpulkan data dengan berbagai teknik, menganalisis data, menarik kesimpulan dan mengomunikasikan konsep, hukum atau prinsip yang ditemukan (Machin, 2014). Keberadaan laboratorium diharapkan mampu menunjang kegiatan-kegiatan yang berpusat pada pengembangan keterampilan tertentu, antara lain keterampilan proses, keterampilan motorik dan pembentukan sikap ilmiah, khususnya pengembangan minat untuk melakukan penyelidikan, penelitian dan minat mempelajari alam secara lebih mendalam (Hudha, 2011).

Mahasiswa jurusan Tadris IPA Biologi dibekali pengetahuan dan keterampilan tentang biologi sebagai bagian dari Ilmu Pengetahuan Alam dan juga dibekali dengan pengetahuan dan keterampilan mengajarkan biologi kepada siswa di sekolah 
nantinya. Oleh sebab itu, penyelenggaraan praktikum dititikberatkan pada membangun tradisi ilmiah atau tradisi saintis kepada mahasiswa. Harapannya ke depan para mahasiswa dapat mewariskan tradisi tersebut kepada siswanya di sekolah. Hal ini penting karena belajar IPA adalah belajar tentang fenomena alam. Menurut Abruscato (2014), tugas guru IPA adalah membantu siswa mekonstruksi pengetahuannya mengenai objek melalui kegiatan ilmiah sebagaimana saintis bekerja. Kegiatan ilmiah yang dilakukan mahasiswa melalui kegiatan praktikum mengasah dan mempertajam keterampilan proses intelektual dalam mempelajari dan membuktikan konsep-konsep biologi.

Penyelenggaraan praktikum di dunia pendidikan termasuk yang diselenggarakan pada Jurusan Tadris IPA Biologi Fakultas Tarbiyah dan Keguruan UIN Mataram sangat bergantung pada kondisi kesiapan sumber daya yang ada. Ketersediaan ruang yang memadai, alat dan bahan praktikum, sumber daya manusia pengelola, dan dukungan kebijakan sangat menentukan pola penyelenggaraan praktikum. Pelaksanaan praktikum tergantung pada materi dan ketersediaan waktu, ketersediaan alat dan bahan, dan pembiasaan mahasiswa dalam memanfaatkan alatalat laboratorium untuk membantu memecahkan masalah masih dinilai kurang (Suryaningsih, 2017).

Adopsi atau inovasi suatu pola penyelenggaraan praktikum tertentu dilakukan dalam kerangka upaya untuk mencapai hasil yang maksimal dengan memanfaatkan sumber daya yang ada. Penelitian yang telah dilakukan ini telah berhasil menguji efektivitas pola praktikum blok 1 × 10 sebagaimana yang biasa dilakukan selama ini dibandingkan dengan pola yang lain yaitu pola $10 \times 1$.

Penelitian yang telah dilakukan di laboratorium IPA Fakultas Tarbiyah dan Keguruan UIN Mataram telah mengambil subjek mahasiswa jurusan Tadris IPA Biologi semester 4 dan mahasiswa jurusan S1 PGMI Semester 2. Penelitian difokuskan untuk menguji efektivitas pola praktikum blok $1 \times 10$ dengan pola $10 \times 1$. Efektivitas yang dimaksud ditinjau dari tiga aspek, yaitu; hasil tes mahasiswa yang menempuh masing-masing pola praktikum, hasil/perolehan nilai laporan praktikum mahasiswa, dan preferensi mahasiswa terhadap salah satu pola praktikum. Di samping itu, peneliti juga menjaring data kelebihan dan kekurangan masing-masing pola praktikum sebagai gambaran alasan mengapa salah satu pola praktikum menjadi pilihan yang terbaik dalam pelaksanaan praktikum pada Laboratorium IPA Fakultas Tarbiyah dan Keguruan UIN Mataram.

Data hasil penelitian dan analisis menunjukkan bahwa, nilai tes mahasiswa yang mengikuti pola praktikum $10 \times 1$ lebih tinggi (66.64) dibanding nilai tes mahasiswa yang mengikuti pola praktikum $1 \times 10$, yaitu 63.90. Secara deskriptif sangat tampak bahwa kemampuan mahasiswa yang mengikuti praktikum pola $10 \times 1$ lebih baik. Hal ini disebabkan pada penyelenggaraan praktikum pola $10 \times 1$ mahasiswa memiliki kesempatan yang lebih untuk melakukan eksplorasi pengetahuan, mencerna informasi/data hasil pengamatan, dan memiliki waktu yang lama untuk menyimpan informasi yang didapat ke dalam memori jangka panjang.

Walaupun secara deskriptif tampak ada pebedaan nilai tes mahasiswa, tetapi secara statistik tidak ada perbedaan yang signifikan antara nilai tes mahasiswa yang mengikuti pola praktikum blok $1 \times 10$ dengan pola $10 \times 1$. Dengan demikian, kemampuan kognitif mahasiswa setelah praktikum dengan kedua pola praktikum tersebut dianggap sama atau setara. Kenyataan ini menandakan bahwa pola praktikum $10 \times 1$ dengan cara praktikum dilakukan setiap kali seminggu tidak merupakan salah satu cara praktikum yang sangat baik dibanding dengan pola 
praktikum $1 \times 10$. Pilihan kebijakan penyelenggaraan praktikum dengan pola $1 \times 10$ selama ini masih bisa dipertahankan karena hasil yang ditampilkan dianggap sama dengan pola $10 \times 1$, sepanjang lembaga masih belum mampu memenuhi jumlah ruang praktikum, alat, dan bahan sesuai banyaknya mahasiswa (kelas) saat ini.

Persoalan mendasar mengapa diterapkan pola praktikum 1 × 10 adalah kekurangan ruang praktikum, termasuk kekurangan alat dan bahan. Pada saat ini, Fakultas Tarbiyah dan Keguruan UIN Mataram hanya memiliki satu ruang praktikum untuk jurusan Tadris IPA yaitu Laboratorium IPA. Laboraotorium IPA ini di samping digunakan untuk praktikum mahasiswa jurusan Tadris IPA Biologi, juga digunakan untuk praktikum mahasiswa jurusan Tadris Matematika dan S1 PGMI pada saat menempuh mata kuliah-mata kuliah dasar, seperti, Fisika Dasar, Kimia Dasar, IPA 1, dan mata kuliah IPA 2. Jika dihitung jumlah mata kuliah yang dipraktikumkan setiap semester rata-rata 3 mata kuliah dan jumlah kelas 15, maka terdapat 45 rombongan praktikum yang harus menggunakan laboratorium setiap minggunya, sehingga untuk menjadwalkan praktikum setiap minggu untuk setiap kelas menjadi sangat sulit. Faktor lain yang menjadi penghambat adalah benturan antara jadwal praktikum dengan jadwal perkuliahan mahasiswa, karena jadwal perkuliahan pada Fakultas Tarbiyah dan Keguruan UIN Mataram mulai jam 07.30 hingga 18.00 WITA. Oleh sebab itu penyelenggaraan praktikum pola $1 \times 10$ merupakan pola yang sangat sesuai dengan kondisi yang ada di UIN saat ini.

Ditinjau dari aspek data nilai laporan praktikum mahasiswa, hasil analisis menunjukkan bahwa, nilai laporan praktikum mahsiswa yang mengikuti pola praktikum $10 \times 1$ lebih tinggi (77.14) dibanding nilai laporan praktikum mahasiswa yang mengikuti pola praktikum $1 \times 10$, yaitu 73.2. Secara deskriptif sangat tampak bahwa kemampuan mahasiswa menyusun laporan praktikum pola $10 \times 1$ lebih baik. Hal ini disebabkan pada penyelenggaraan praktikum pola $10 \times 1$ mahasiswa memiliki waktu yang lama untuk mencari dan mempersiapkan materi yang diperlukan dalam menyusun laporan praktikum, karena isi laporan praktikum memuat tulisan/deskripsi, gambar, tabel, grafik, perhitungan matematis, dan lain-lain. Dalam penyusunan laporan praktikum, mahasiswa memerlukan literatur yang banyak untuk digunakan sebagai dasar teoritis bagi pelaksanaan praktikum tersebut. Di samping itu, juga perlu waktu yang cukup bagi mahasiswa untuk menganalisis dan membahasakan data yang diperoleh dalam percobaan atau pengamatan. Pada umumnya suatu aktivitas praktikum diikuti oleh pembuatan laporan yang berupa tulisan, gambar, tabel, grafik, hasil koleksi, jawaban pertanyaan, dan sebagainya untuk membuktikan bahwa mahasiswa telah melakukan dan mempelajari praktikum yang ditugaskan (Parjatmo, Anna, \& Krisna, 1997; Padmawinata, 1981).

Sebagaimana nilai tes kemampuan mahasiswa, secara deskriptif tampak ada perbedaan nilai laporan praktikum mahasiswa, tetapi secara statistik tidak ada perbedaan yang signifikan antara nilai laporan praktikum mahasiswa yang mengikuti pola praktikum blok $1 \times 10$ dengan pola $10 \times 1$. Dengan demikian, kemampuan mahasiswa menyusun laporan praktikum setelah praktikum dengan kedua pola praktikum tersebut dianggap sama atau setara. Kenyataan ini menandakan bahwa, ditinjau dari aspek penyusunan laporan praktikum pola praktikum $10 \times 1$ dengan cara praktikum dilakukan setiap kali seminggu tidak merupakan salah satu cara praktikum yang sangat baik dibanding dengan pola praktikum 1 x 10 .

Penelitian ini juga berhasil menghimpun data preferensi mahasiswa/praktikan dan co-asisten terhadap salah satu pola praktikum. Preferensi yang dimaksud adalah frekuensi mahasiswa yang paling banyak memilih salah satu pola praktikum. Hasil 
analisis data angket, menunjukkan bahwa 33 orang (96\%) mahasiswa dan co-asisten menyatakan lebih menyukai pola praktikum $10 \times 1$ atau praktikum yang dilaksanakan setiap minggu. Dua orang mahasiswa dan co-asisten (6\%) menyukai praktikum dengan pola $1 \times 10$. Dengan demikian, dapat dikatakan bahwa pola praktikum $10 \times 1$ lebih disukai mahasiswa dan co-asisten dibanding pola $1 \times 10$. Kenyataan ini bisa dimaklumi karena pelaksanaan praktikum yang dilakukan setiap minggu memberikan ruang dan waktu yang cukup bagi mahasiswa dan co-asisten. Mereka bisa mempersiapkan segala sesuatu yang diperlukan dalam praktikum, misalnya mempersiapkan diri untuk mengikuti kegiatan respon awal (pretes). Mahasiswa juga dapat merencanakan pekerjaan penulisan laporan secara terencana, tanpa harus terburu-buru.

Dari aspek yang ditinjau di atas, menggambarkan bahwa secara deskriptif pelaksanaan praktikum dengan pola $10 \times 1$ lebih efektif dibanding pola $1 \times 10$. Namun secara statistik menunjukkan bahwa pelaksanaan kedua pola praktikum tersebut tidak menunjukkan hasil yang berbeda secara signifikan, atau sama saja. Oleh sebab itu pelaksanaan praktikum pola 1 × 10 masih dapat direkomendasikan menjadi kebijakan pelaksanaan praktikum pada Laboratorium IPA Fakultas Tarbiyah dan Keguruan UIN Mataram.

\section{KESIMPULAN}

Hasil studi menunjukkan bahwa tidak ada yang paling efektif penyelenggaraan praktikum antara pola blok $1 \times 10$ dan pola $10 \times 1$ ditinjau dari aspek kemampuan kognitif mahasiswa setelah praktikum dan nilai laporan praktikum mahasiswa. Walaupun demikian, secara deskriptif hasil studi ini menunjukkan bahwa penyelenggaraan praktikum pola $10 \times 1$ memberikan hasil yang lebih baik dan lebih disukai oleh mahasiswa dibanding pola blok $1 \times 10$.

\section{SARAN}

Penelitian ini tidak meninjau perbedaan efektifitas pola praktikum berdasarkan preferensi mahasiswa sehingga perlu dilakukan penelitian lebih lanjut terkait perbedaan efektifitas pola praktikum berdasarkan preferensi mahasiswa tersebut, mengingat preferensi mahasiswa lebih condong pada salah-satu pola praktikum.

\section{UCAPAN TERIMAKASIH}

Penelitian ini tidak menerima hibah khusus dari agensi pendanaan mana pun di sektor publik, komersial, atau nirlaba.

\section{DAFTAR PUSTAKA}

Abruscato. (2014). Teaching Children Science: A Discovery Approach. New York: Allyn and Bacon.

Ali, L. U. (2018). Pengelolaan pembelajaran IPA Ditinjau dari hakikat sains pada SMP di Kabupaten Lombok Timur. Prisma Sains: Jurnal Pengkajian Ilmu Dan Pembelajaran Matematika Dan IPA IKIP Mataram, 6(2), 103. https://doi.org/10.33394/j-ps.v6i2.1020

Carin. (1999). Teaching Modern Science. New York: Macmillan Publishing Company. Hodson, D. (1996). Practical work in school science: Exploring some directions for change. International Journal of Science Education, 18(7), 755-760. https://doi.org/10.1080/0950069960180702

Hudha, A. M. (2011). Analisis pengelolaan praktikum biologi di laboratorium biologi. 
Jurnal Penelitian Dan Pemikiran Pendidikan, 1(1), 37-51.

Istiana, N., Sarwi, \& Masturi. (2016). Penerapan Model Pembelajaran Kooperatif STAD untuk Meningkatkan Penguasaan Konsep dan Keterampilan Proses Belajar Fisika. Unnes Physics Education Journal, 5(1).

Machin, A. (2014). Implementasi pendekatan saintifik, penanaman karakter dan konservasi pada pembelajaran materi pertumbuhan. Jurnal Pendidikan IPA Indonesia, 3(1), 28-35.

Mao, S.-L., \& Chang, C.-Y. (1998). Impacts of an inquiry teaching method on earth science students' learning outcomes and attitudes at the secondary school level. Proc. Natl. Sci. Counc. ROC(D), 8(3), 93-101.

Marcella, Z., Susanti, N., \& Dani, R. (2018). Analisis hambatan pelaksanaan praktikum IPA terpadu di SMPN 17 dan SMPN 19 Kota Jambi. Jurnal EduFisika, 3(2), 42-48.

McDermott, L. C. (1990). A perspective on teacher preparation in physics and other sciences: The need for special science courses for teachers. American Journal of Physics, 58(8), 734-742. https:// doi.org/10.1119/1.16395

Nugent, G., Kunz, G., Levy, R., Harwood, D., \& Carlson, D. (2008). The impact of a field-based, inquiry-focused model of instruction on preservice teachers' science learning and attitudes. Electronic Journal of Science Education, 12(2), 1-18.

Padmawinata. (1981). Manajemen Laboratorium IPA Sekolah. Bandung: Rosdakarya.

Parjatmo, Anna, \& Krisna. (1997). Panduan Praktikum Biologi Umum. Bandung: Penerbit Angkasa.

Rochmawati, A., Wiyanto, \& Ridlo, S. (2019). Analysis of 21 st Century Skills of Student on Implementation Project Based Learning and Problem Posing Models in Science Learning. Journal of Primary Education, 9(1), 58-67.

Ruse, M. (2012). What the philosophy of biology is: essays dedicated to David Hull. Springer Science $\backslash \&$ Business Media.

Siburian, F., Sinambela, M., \& Septie. (2014). Analisis Pelaksanaan Praktikum pada Mata Pelajaran Biologi. Jurnal Pelita Pendidikan, 5(2), 21-31.

Sudarisman, S. (2015). Memahami Hakikat Dan Karakteristik Pembelajaran Biologi Dalam Upaya Menjawab Tantangan Abad 21 Serta Optimalisasi Implementasi Kurikulum 2013. Florea: Jurnal Biologi Dan Pembelajarannya, 2(1), 29-35. https:// doi.org/10.25273/florea.v2i1.403

Suryaningsih, Y. (2017). Pembelajaran Berbasis Praktikum sebagai Sarana Berlatih Menerapkan Keterampilan Proses Sains. Jurnal Bio Educatio, 2, 49-57.

Susanti, M., Rusilowati, A., \& Susanto, H. (2015). Pengembangan Bahan Ajar IPA Berbasis Literasi Sains Bertema Listrik dalam Kehidupan unruk Kelas IX. Unnes Physics Education Journal, 4(3).

Trnova, E., \& Trna, J. (2015). Formation of Science Concepts in Pre-school Science Education. Procedia - Social and Behavioral Sciences, 197(February), 2339-2346. https://doi.org/10.1016/j.sbspro.2015.07.264

Trumper, R. (2002). What do we expect from students' physics laboratory experiments? Journal of Science Education and Technology, 11(3), 221-228. https://doi.org/10.1023/A:1016016417872

Tuckman. (1978). Conducting Educational Research. New York: Harcourt Brace Jovanovich.

Vyjantimala, Lum, Mui, \& Hong. (2002). Science Exploration. Singapura: Oxford University Press.

Wijaya. (2002). Analisis SPSS: Statistik Parametrik. Bandung: Alfabeta. 